[7225 Words]

\title{
Men, Women and Unions
}

\begin{abstract}
The paper examines whether gender dynamics contributed to the decline of unions. To this end, it reviews different strands of the literature and conducts empirical analyses using data from WERS. The results obtained confirm that men have been deserting unions and that there is an inverse link between membership and the share of women in the workplace. The paper ponders if better management of gender relations may contribute to unions' renewal.
\end{abstract}

Key words: Workplace gender composition, Union decline, employer-employee data, Britain. JEL classification: $J 16, J 51, J 82$ 


\section{Introduction}

There is extensive literature on the decline of unions in Britain since the 1970s. Some of the key reasons underpinning the sweeping decline include unions' failure to organise in new establishments, particularly outside of their traditional manufacturing base; increased competitive pressures; legislative changes and changes in the composition of the workforce (Blanchflower and Bryson, 2008; Bryson 2008; Blanden et al. 2006; Machin 2000, 2003; Disney et al. 1995, 1996; Freeman and Pelletier 1990). A concomitant feature of the labour market over this period has been the increase in the share of women in workplaces - dubbed as the "influx of women" (Parker, 2002, p. 23) - which changed the gender composition of workplaces and unions. ${ }^{1}$ As argued in a recent paper (Haile, 2016), unions are voluntary institutions that flourish on coalition-building within the workforce. The increase in the workplace share of women and divergent interests between men and women within unions might have frustrated coalition-building, contributing to unions' decline. Existing evidence on gender discrimination in workplaces and within unions lends some support to this argument. On the other hand, unions' role in the employment relationship and women's labour market behaviour are such that they are more likely to be unions' natural allies. If so, and if the growing segment of the labour force was to join unions, then their decline must have been due to men abandoning unions.

This paper examines whether there is intra-union gender dynamics contributing to the decline of unions. To this end, first, it presents a review and synthesis of available evidence from three strands of the literature on unions' role in the employment relationship; gender differences in competition and risk preferences, and gender dynamics within unions. Secondly, it conducts empirical analysis using data from the 2004 and 2011 waves of the British

\footnotetext{
${ }^{1}$ Recent official figures reveal that the gap in the labour market participation rate between men and women has declined from 14.5 (1994) to 8.8 (2014) percentage points in favour of the latter (ONS, 2014).
} 
workplace employment relations survey (WERS). The paper is unique in its review and synthesis of available evidence from three different strands of the literature. It also provides empirical evidence on whether it is men or women who have been deserting unions. In addition, it determines whether there is a link between union decline and the share of women in workplaces. In addition, its use of two sweeps of the rich WERS data as well as the conduct of both employee- and workplace-level analyses lend the paper significant strength than what has been done previously.

The review and synthesis of existing evidence points to divergent interests between unions, the power structures of which are still dominated by men, and women. This suggests a possibly conflict laden union environment. The empirical results obtained reveal that: $(i)$ men, rather than women, have been deserting unions and (ii) there is an inverse link between union density and the share of women in the workplace, which is supported by results from both the employee- and workplace-level analyses. The paper mulls over if improved management of gender relations within unions, and workplaces generally, may contribute to unions' renewal.

The remainder of the paper is organised as follows. Section Two, provides a review and synthesis of the evidence from three strands of the literature and develop two testable hypotheses. Section Three describes the data and variables used. Section Four sets out the empirical framework used. Section Five discusses the results obtained before the final section concludes the paper.

\section{Review of literature}

There are different strands of the literature, which inform the analysis seeking to establish possible link between union decline and gender dynamics. The following sub- 
sections elaborate on each of these strands of the literature, with a view to developing testable hypotheses.

\subsection{Unions' role in the employment relationship}

Unions are voluntary institutions with the traditional role of organising workers for collective bargaining (Freeman and Medoff, 1984). They also provide insurance against various employment risks, primarily by allocating such risks between the employer and the employee, thereby enhancing productivity (Malcomson 1983; Acemoglu et al. 2001). Historically, worker movements have also played a vital role in ensuring workplace safety, which firms might not have delivered of their own accord due to cost considerations (Donado and Walde 2012). Unions are of course thought to provide mutual insurance - in the sense of 'unions support me if I have a problem at work' - including in situations of gender discrimination (see, for example, Waddington and Whitston 1997; Healy and Kirton 2013). Women's labour market histories are generally characterised by interruptions due to shouldering child care and domestic responsibilities more than their male counterparts do (Hotchkiss and Pitts 2007; Phipps et al. 2001; Blau and Kahn 2000). Such interruptions - or employers' perceptions of them - are likely to put women at a greater employment risk than men, making them more inclined to join unions to minimise such employment uncertainties.

\subsection{Men, women and differences in risk preference}

A number of recent experimental studies highlighted gender differences in risk preference, social preference and reaction to competition. This evidence suggests that women are generally more risk- and competition-averse as well as being more sensitive to social cues than men (Gneezy et al. 2003; Croson and Gneezy 2009; Eckel and Grosmann 2008; Niederle and Vesterlund 2007). Booth (2009) argues that such gender differences in preferences "can 
be shaped by the environment in which individuals are placed" (p. 605) and unlikely to be due to innate psychological differences between men and women. In a more recent study Booth and Nolen (2012) pursued this argument and conducted empirical analysis using a controlled experiment. The results they obtained allowed them to reject the earlier evidence that the average female avoids competition vis-à-vis her male counterpart. They emphasised that observed gender differences are reflective of social learning rather than being inherent gender traits. Azmat and Petrongolo (2014) emphasis that there are still key outstanding questions on whether observed gender differences are due to nature or nurture, or the role such differences play in the workplace setting. Nonetheless, the overarching evidence points to gender differences in competition and risk preferences.

\subsection{Men, women and gender dynamics within union}

A body of research evidence points to widespread gender discrimination in workplaces in Britain (see, for example, Riach and Rich 2006, Arulampalam, et al. 2007, Berthoud and Blekesaune 2007, Booth, 2009, Haile 2016), which is also reported to be an attribute of the within union environment where men still dominate union power structures. There is evidence of some progress towards gender representations within the union powerstructure more recently. However, this appears to be limited. Having examined the position of women in the recent modernisation process of British trade unions, Mark et al. (2013) noted that, “...there was little evidence that they [i.e. the modernisation projects] had fostered change in gender parity among senior union officials" (p. 57). Importantly, many argue that translating limited gain in gender representations into actions directed at enhancing women's experience within unions and workplaces remains a major challenge. In fact, there are calls that gender democracy become an integral part of the union renewal process rather than being secondary to the union survival agenda (Kirton 2015; Healy and Kirton 2013; Cobble 2007; Kirton 2006; 
Kirton and Greene 2002; Healy and Kirton 2000, Dickens 1997). Unions' exclusive focus on improving basic terms and conditions without paying much attention to the specific concerns of women has long been criticised (Metcalf 2000). However, the recent significant increase in women's share of the labour force seems to have given new impetus to such criticisms. Parker (2006) highlights this by pointing the complexity of relations between unions and women's groups who challenge elements of the union and the status quo. This is partly due to particular difficulties women face - or are perceived to face - in balancing union participation and/or leadership with other areas of life (Bradley and Healy 2008; Kirton 2006). Regardless, there are reasons to suspect that the within union environment may be strained along gender lines, which may not necessarily bode well with consensus-building, which unions need.

\subsection{A synthesis of the available evidence and testable hypotheses}

The reivew in the preceding paragraphs shows that unions still have important roles to play in today's world in providing insurance, reducing risk and augmenting economic efficiency generally. In fact, it can be argued that in some sense the need for union provided insurance against employment risks has deepened today than during unions' heyday for several reasons. First, there has been an "influx" of women - unions' more risk-averse constituents into workplaces in Britain in recent decades. Women also face more employment risks than men do due to their labour market characteristics. Therefore, they are expected to demand unions' service more than men. Secondly, although it is widely accepted that the service sector is generally more difficult to organise than manufacturing, productivity is hard to monitor in the sector than in manufacturing. Given Malcomson (1993)'s argument, therefore, employers in the sector may be more risk averse, which makes unions still relevant as they allocate such risks between employers and employees. Thirdly, there is evidence that "atypical" employment has grown in importance recently and women feature in it more (Greene and Kirton 2006; 
Howell 1996). Atypical employees are hard to organise in the traditional sense of the term. However, such employees bear significant additional employment risks due to the nature of their employment contracts, which may push them into joining unions. Fourthly, there is evidence of a growing stress and mental health problems in Britain (Vickerstaff et al., 2012; HSE, 2009), which may mean a higher demand for unions' service towards better occupational health and safety standards. Fifthly, globalisation has generally brought about increased product and factor market competition and, with it, increased employment uncertainties, which may be greater for women than men.

Altogether, one expects women to be drawn more towards joining unions seeking union provided insurance against the greater employment risks they face. Indeed, available evidence shows that this is the case. Kirton and Healy (2013) report that women constitute over 50 percent of union members in Britain currently; and more women than men are joining unions. If the share of women in workplaces in Britain has been increasing and women are embracing unions more than ever before, then it is highly likely that the decline in union membership is due to men abandoning unions.

Hypothesis 1: Men are more likely than women to abandon unions.

This hypothesis will be tested based on employee-level empirical analysis. If, as proposed by hypothesis 1 , men have been abandoning unions, what could the reason for this be? As pointed in Croson and Gneezy (2009), men's relative disposition towards risk-taking could be one explanation. Also, men might have been leaving unions in search of better outside opportunities rather than the union endorsed compressed wage (Acemoglu et al. 2001). Though appealing, however, these may not provide sufficient explanation since the same risk-taker and enterprising men used to be championing unions in the past. This makes intra-union gender 
dynamics as a plausible explanation for union decline. A number of recent studies have highlighted the link between employee-level outcomes and workgroup identity including gender composition (see, for example, Akerlof and Kranton 2010, 2000; Alesina and La Ferrara 2002). It has also been argued that identity - or the desire to act as members of one's own group - is one of the three fundamental reasons why people join a union movement (Klandermans 2009; Healy and Kirton 2013). Given these, intra-union gender dynamics with a possibly conflict-laden union environment may be a credible explanation. If so,

Hypothesis 2: Union density is negatively related to the share of women in the workplace.

This hypothesis will be tested using both employee- and workplace-level empirical analyses, which are detailed in the analytical approach section below. One important consideration in the union discourse is the marked difference between the public and the private sectors, notwithstanding some recent convergence between the sectors in employment practices that is driven by modern public sector management practices and the recent cut in public expenditure (Bach et al., 2009; Bach, 2012; van Wanrooy et al. 2013). Taking these into account, the empirical analyses conducted seek to highlight sectoral differences in the proposed link between intra-union gender dynamics and union decline.

\section{Data and variables}

\subsection{Overview of the Data}

The data come from the 2004 and 2011 British Workplace Employment Relations Surveys (WERS), the most authoritative linked employer-employee data on employment relations in Britain representative of all workplaces with five or more employees. That the data 
cover large number of demographically varied workplaces providing ample opportunity to examine possible link between workforce gender composition and union decline. The data cover a range of issues relating to both employees and employers as well as geographic information, which allow controlling on a battery of individual- and workplace-level characteristics including possible regional variations in the link between gender and union decline. The employer surveys management questionnaires, which were completed in a faceto-face interview with managers in charge of the day-to-day task of employment relations. The employee surveys, on the other hand, used self-completion employee questionnaires, which were completed by up to 25 employees in participating workplaces (Kersley et al. 2006; van Wanrooy et al. 2013).

The 2004 and the 2011 WERS surveys monitored 2295 and 2680 workplaces, respectively, and 22,451 and 21,981 employees in each wave. 989 of the establishments were surveyed in both waves, so offering a panel data on a sub-set of the WERS establishments. However, the employees surveyed were not the same so WERS does not provide a panel data on employees. The employee-level analysis conducted uses 11,353 and 11,183 employees from the 2004 and 2011 surveys, respectively, which are net of those employees who were never union members $(10,402$ in 2004 and 10,143 in 2011) who are not relevant for our analysis; and those with missing values on relevant variables. Because the surveys are not panel in employees, the employee-level analysis conducted uses the pooled sample of 22,536 employees. Similarly, the workplace-level analysis relies on the original sample of establishments less those with missing values on relevant covariates. This yielded 2050 and 2330 workplaces in 2004 and 2011, respectively, of which there were a panel of 773 workplaces surveyed in both waves.

\subsection{Definition of variables}




\subsubsection{Outcome variables}

The outcome measure for the employee-level analysis comes from employees' response to the question 'Are you a member of a trade union or staff association?' Employees provided one of the following three responses: (i) "yes", (ii) "no, but have been in the past" and (iii) "no, have never been a member". The third response category does not provide useful information for this study. As a result, the employee-level outcome variable is a dummy variable (past union member) that takes the value 1 if an employee provided the second response and 0 otherwise. The workplace-level analysis uses union density as an outcome measure, which is derived from employers' response to the following two questions: (i) 'how many employees at this establishment are members of a trade union or independent staff association - whether recognised by management or not?' $\left(n_{j}^{u}\right)$ and (ii) 'Currently how many employees do you have on the payroll at this establishment?' $\left(N_{j}\right)$. On the basis of the responses provided to these questions a percentage measure of workplace union density $(U D)$ has been generated for each workplace as; $U D=\left(n_{j}^{u} / N_{j}\right) \times 100$.

\subsection{2. \% female and other control variables}

The employee-level analysis controls for a range of employee, workplace and geographic characteristics while the workplace-level analysis controls for workplace and geographic characteristics, which include workplace size, industry, ownership type and a count measure of workplace equality practices. The main control variable for both analyses is the "\% female" measure. It is obtained from employers' response to the questions: (i) 'how many women work full-time' $\left(n^{f 1}{ }_{j}\right)$ and (ii) 'how many women work part-time' $\left(n^{f 2}{ }_{j}\right)$. Combining the responses to these yields the total number of female employees in a workplace $\left(n_{j}^{f}=n^{f 1}{ }_{j}+n^{f 2}{ }_{j}\right)$. "\% female" is then obtained as: \% female $=\left(n_{j}^{f} / N_{j}\right) \times 100$. 


\section{Analytical framework}

The analytical approach adopted involving three different types of models. The first type, which relies on the employee-level binary outcome measure ("past union member"), uses a two-level multilevel model, which exploits the nested structure of the WERS data. The model, which will allow testing both Hypotheses, has the following general form:

$$
y_{i j}=\alpha+\boldsymbol{\beta}^{\prime} \mathbf{x}_{i j}+\boldsymbol{\delta}^{\prime} \mathbf{w}_{j}+\mu_{j}+\varepsilon_{i j} ; \quad i=1, \ldots, N \text { and } j=1, \ldots, M
$$

where $y$ represents the binary outcome measure of whether employee $i$ in workplace $j$ was a union member in the past. The vector of employee characteristics is represented by $\mathbf{x}$ while the vector of workplace characteristics is represented by $\mathbf{w}$. The model assumes that the workplacelevel unobserved characteristics $\mu_{j}$ and the idiosyncratic error term $\varepsilon_{i j}$ are distributed normally. Equation (1) is estimated using the random-intercept model, which allows partitioning the unexplained variation in our outcomes into workplace-level variance representing unobserved workplace heterogeneity and a residual variance term. We also use the same binary employeelevel outcome measure to test Hypothesis 2. This is achieved with a variant of model (1), which includes an additional term - an interaction term between the employee-level information ("male") and the workplace-level information ("\% female"). In both cases, estimation is conducted using STATA's “xtmelogit” suit, which estimates multilevel mixed-effects logistic regression.

The second type of regression analysis relies on the workplace-level outcome measure "union density". Strictly speaking this outcome measure is a proportion, which is best modelled using fractional response models (Papke and Wooldridge 1996; Baum 2008; Williams 2017). ${ }^{2}$

\footnotetext{
${ }^{2}$ Baum (2008) emphasises on this point that “...it is not appropriate strategy [to use censored normal regression] as values outside the $[0,1]$ interval are not feasible for proportions data" (p.302).
} 
Taking this into account, we first estimate Generalised Linear Models (GLM) using STATA's "glm" suits on each of the 2004 and 2011 cross-sections separately as well as pooled together. The GLM approach involves a logit transformation of the fractional response outcomes and the binomial distribution to estimate the model. Aside from its suitability to the fractional workplace-level outcome measure, the implementation of this specification also renders a much larger workplace sample size.

Finally, the paper implements linear panel data regressions using the panel of 773 workplaces, which were surveyed in 2004 and 2011. These involve pooled OLS, RandomEffects (RE) and Fixed-Effects (FE) regressions, which assume the workplace-level outcome to be continuous. The latter two have a general form of the following type;

$$
y_{j t}=\alpha_{t}+\boldsymbol{\beta}^{\prime} \mathbf{x}_{j t}+\boldsymbol{\delta}^{\prime} \mathbf{w}_{j}+\mu_{j}+\varepsilon_{j t} ; \mathbf{j}=1, \ldots, N \& \mathbf{t}=2(2004,2011)
$$

where $y$ this time represents the union density outcome, $j$ indexes workplaces as before, $t$ represents time period $(\mathrm{t}=2), \mathbf{x}$ here represents the vector of time varying workplace characteristics, w represents the vector of time invariant workplace characteristics, $\mu_{j}$ is the time invariant unobserved workplace characteristics and $\varepsilon_{j t}$ is the random error term. We estimate these models using STATA's "reg" (pooled OLS) and "xtreg" suits. Aside from the potential drawback of using these models for estimating a fractional outcome measure, the much smaller sample size may also render these less reliable in terms of the robustness of the estimation results in addition to being restrictive of further sub-group analysis.

\section{Results and discussion}

The results from the employee-level analysis are reported in Tables 1 and 2 below, each of which are based on two different specifications that control for only employee 
characteristics (left panel) and both employee and workplace characteristics (right panel). ${ }^{3}$ According to the results in Table 1, which are marginal effects from multilevel mixed-effects logistic models on the pooled 2004 and 2011 samples, men are significantly likely to be past union members. A sectoral pattern also emerges in that men in the private sector were generally a lot more likely to have been past union member vis-à-vis their counterparts in the public sector. This is in line with what would be expected given that much of the union decline in most recent decades has taken place in the private sector. At any rate, these results lend support to Hypothesis 1.

[Insert Table 1 - about here]

Table 2 provides results from a similar exercise as before; but this time by including "\% Female" control and its interaction with "male". This provides further evidence for Hypothesis 1. In addition, the interaction term provides important evidence related to Hypothesis 2, i.e. whether the workplace share of female employees (\% Female) is linked to men abandoning unions. Estimated marginal effects on the interaction terms are positive and highly statistically significant throughout. This suggests that, firstly, men are more likely to be past union members, which reinforces our earlier finding ${ }^{4}$. Secondly, the results also reveal a positive link between past union membership status, again a predominantly male characteristics, and the share of female employees at the workplace. In other words, where the share of female employees in the workplace increased, the likelihood of abandoning unions [by men] also increased.

\footnotetext{
${ }^{3}$ The corresponding full regression Tables are provided in the Appendix as Tables A1 to A4.

${ }^{4}$ If reduced version of the "past member" equation were to be given by: PM=a*Male $+b^{* \% \text { Female }+}$ c*Male*\%Female; then the "male effect" would be given by: a $+\mathrm{c} * \%$ Female, which needs to be evaluated at the mean value of $\%$ Female yielding positive effects in all cases. On the other hand, the "\%Female effect" would be given by: $b+c$, which is again positive in all cases except the combined sample in 2004 .
} 
Even though men in the private sector are likely to be past union members as the results in Table 1 show, it is notable that the adverse link between past membership and \%Female is stronger in the private sector, albeit marginally. Once again, these results provide support to Hypothesis 2.

[Insert Table 2 - about here]

Table 3 reports results from the workplace-level analysis, which are marginal effects obtained from Generalised Linear Models estimated on the 2004 and 2011 cross-sections separately and pooled together. The models controlled for workplace characteristics such as age, size, industry and region. The top panel of the results in Table 3 relates to the pooled sample while the middle and bottom panels relate to the 2004 and 2011 cross-sections respectively. The marginal effects indicate that workplace union density is negatively and statistically significantly related to the share of women employees in the workplace for the combined public and private sector workplaces. Thus, once again these results lend support for Hypothesis 2. On the other hand, the workplace-level analysis suggests that the negative link found is largely a feature of the private sector, with no significant link found for the public sector in 2011 and the pooled samples. This is not entirely consistent with the results from the employee-level analysis. However, this is likely to be borne out of sample size differences between the much larger employee and workplace samples.

[Insert Table 3 - about here]

Figure 1 depicts plots of predicted union densities and \% Female, which are depicted separately for the 2004 and 2011 cross-sections and disaggregated by type of sector. In both 
cases, predicted union density declines almost linearly with the share of women in the workplace. The plots also show that the inverse link found between predicted values of union density and the share of women are stronger (steeper) in the public sector than its private sector counterpart in both 2004 and 2011. Comparing these patterns between the years, the drop in the public sector is marginally higher in 2011.

[Insert Figure 1 - about here]

Table 4 reports alternative estimation results from the workplace-level analysis using Pooled OLS (top panel) and linear panel data models (RE and FE, middle and bottom panels respectively) on the 773 panel workplaces. The OLS and RE results do more or less appear to reinforce the earlier findings on the inverse link between union density and the share of women in the workplace. However, the sectoral differences we observed earlier appear to have been reversed here, with the estimates marginally stronger for the private sector. On the other hand, the results from the FE model reveal a much weaker inverse link between union density and the workplace share of women. The effect found is also weakly significant only for the private sector. Overall, it can be argued that these results lend at best weak evidence in support of Hypothesis 2. In fact, on the basis of the results from the FE model, which is best placed to deal with potential endogeneity problems, one may argue that there is hardly any evidence of an inverse link between union density and the share of women at the workplace. On the other hand, it is worth pointing that the FE model is highly restrictive in the current context, given the nature of the data used. First, the workplace-level outcome (union density) is a nonlinear (fractional) measure, which should not ideally be modelled using the linear models as argued by Baum (2008). Secondly, the panel data used is very short $(t=2)$, which is the bare minimum requirement for implementing the panel data estimation procedures. The FE procedure, in 
particular, requires sufficient within-group dynamics in the form of repeated observations and variations in the controls to make a good sense. Moreover, the 7 year time gap between the two waves makes it harder to justify the presence of unobserved time-invariant characteristics over such a long time gap, which affect the dependent and control variables simultaneously. Thirdly, the public-private sector split in our data is not balanced with the public sector accounting for only $29.5 \%$ (2004) and $28.6 \%$ (2011) of the workplaces in the estimation sample. Even more troubling is the distribution of unionised workplaces between the public and the private sectors among the panel of workplaces, where 95.61 (2004) and 96.83\% (2011) of the workplaces in the public sector are unionised against $44.04 \%$ and $44.02 \%$ in the private sector. These and the inability to use a number of the time invariant observable characteristics such as geographic region, which are quite important in explaining union membership dynamics, may be the reason for the poor overall fit of the FE model as evidenced by the F-statistics reported in the table, especially for the sub-group analysis.

\section{[Insert Table 4 - about here]}

Overall, the employee-level analysis does lend a fairly clear evidence in support of Hypotheses 1 and 2 we proposed. The workplace-level analysis, which is only appropriate for testing Hypothesis 2, does also provides some support for Hypothesis 2. However, some caution may have to be exercised here, given the weaker link the FE model delivered, however restrictive the model is for our data as pointed earlier. If, in the final analysis, we accept that the weight of the results found are in support of Hypotheses 1 and 2, then the natural question that should follow is what might be the underlying mechanism at play as regards to the inverse link between union density and the share of women in the workplace? Our data only permits empirically establishing the nature of the link that may exist; but not the reasons for the 
observed patterns unfortunately. However, the evidence in the literature we reviewed makes the intra-union and/or intra-workplace gender dynamics a strong suspect. As argued earlier, if: (i) more and more women are joining the workplace and more of them are joining unions to circumvent various employment risks and (ii) the union power structure is still largely dominated by men whose primary preoccupation remains to be basic terms and conditions (and not women's interests), then it may not be entirely inconceivable that the internal union environment gets strained. If so, it is not surprising that the party facing relatively less employment risks or is relatively less risk-averse - men - were to abandon unions, as the results obtained reveal.

\section{Summary and conclusion}

The paper attempted to study whether there is a link between the increase in the workplace share of women and the decline of unions in Britain. To this end, it made extensive review of three different strands of the literature as well as conducting employee- and workplace-level empirical analyses using data from the 2004 and 2011 WERS surveys. The review of the literature highlighted that unions do still have important roles to play in today's world in terms of providing insurance to employees, reducing employment risks and augmenting economic efficiency. There is also overarching evidence showing that women are more competition- and risk-averse than men, although such differences are thought to be the result of nurture rather than nature. The paper argued that unions should have been boosted at a time when there is an "influx" of women - unions" more risk-averse constituents - into workplaces in Britain in recent decades. Also, the "influx" of women is mostly into the services sector and often in the form of "atypical" employment. Although there is a broad consensus that the service sector is hard to organise, it is plausible that employment in the sector generally and the "atypical" type particularly represent higher degrees of employment uncertainty. This 
coupled with the still dominant domestic role women play, which contributes to their interrupted labour market histories, are likely to draw women more towards unions, with more of them joining unions. Indeed, the evidence in the literature showed that more women than men are union members currently, constituting over 50 percent of members, and more women are still joining unions.

The paper argued that if the share of women in workplaces in Britain has been increasing and women are likely to become union members, then it is highly likely that the decline in union membership is the result of men abandoning unions. The paper questioned if there may be a within union gender dynamics that has led men to desert unions thereby contributing to their decline. There is evidence in the literature, which points to the traditional union agenda being challenged by women's groups. The paper sought to explore this angle and proposed two testable hypotheses to this end. It then conducted empirical analysis using data from the 2004 and 2011 WERS surveys and deploying alternative empirical approaches.

The results obtained lend support to the hypotheses proposed. Specifically, men are found to be significantly more likely to have been union members in the past. This suggests that compared to women, men have been abandoning unions. The employee-level empirical analysis conducted also provided statistically significant positive link between past membership status and the share of women in the workplace. The workplace-level analysis also offered some evidence pointing to a negative and strongly significant link between workplace union density and the percentage of female employees. This suggests that where the share of women is higher, the decline of unions is more severe. If men abandoning unions is to be one of the reasons for the decline of unions and if such a decline is found to be more severe where the workplace share of women is higher, then this seems to suggest that men's departure from unions may have something to do with the increase in the proportion of women in workplaces/unions and the gender dynamics therein. 
The paper is rigorous in many respects including: its extensive review of different strands of the literature, its use of rich data from the WERS surveys as well as its implementation of alternative analytical methods to test the hypotheses it proposed. Overall, the results obtained from the employee-level analysis lend strong support for the hypotheses we proposed. The workplace-level analysis also provides support for the second hypothesis, which it was meant to test. However, the results from one of the specifications in the workplace-level analysis, viz. FE model, lend only a weak support. The FE model is a highly restrictive specification, given the data limitations discussed in the preceding section. Still, the results from the workplace-level analysis may have to be read cautiously. It is thus needless to point about the necessity for more research of this type, particularly where there is workplacelevel membership information over a period of time with a gender disaggregation. Such data would allow a fuller picture in terms of the gender patterns in union membership over time. It is likely that our gender aggregated membership data has led to the underestimation of the decline in men's membership, if their departure from unions was to be compensated by more and more women joining unions. Equally important is the need for qualitative analyses, which are better placed in terms of teasing out precisely why men might have been abandoning unions. 


\section{References}

Acemoglu, D., Aghion, P. and Violante, G. (2001) Deunionization, Technical Change and Inequality, Carnegie-Rochester Conference Series on Public Policy, 55, 229-264.

Akerlof, G. and Kranton, R. (2000) Economics and Identity, The Quarterly Journal of Economics, 115 (3), 715-753.

Akerlof, G. and Kranton, R. (2010) Identity Economics: How Our Identities Shape Our Work, Wages, and Well-being, Princeton University Press.

Alesina, A. and La Ferrara, E. (2002), Who trusts others? Journal of Public Economics, 85, 207-34.

Arulampalam, W., Booth, A., Bryan, ML. (2007), Is there a glass ceiling over Europe? Exploring the gender pay gap across the wages distribution, Industrial and Labor Relations Review, 60 (2), 163-186.

Azmat, G. and Petrongolo, B. (2014), Gender and the labour market: What have we learned from field and lab experiments? Labour Economics, 30, 32-40.

Bach, S., Kolins, R. and Forth, J. (2009), The Public Sector in Transition, pp. 307 - 331, in W. Brown, A. Bryson, J. Forth and K. Whitfield (eds.), The Evolution of the Modern Workplace, Cambridge: Cambridge University Press.

Bach, S. (2012), Shrinking the state or the Big Society? Public service employment relations in an era of austerity, Industrial Relations Journal, 43 (5), $399-415$.

Baum, C. (2008), Modelling Proportions, The Stata Journal, 8 (2), 299-303.

Berthoud R and Blekesaune M (2007) Persistent employment disadvantage, Department for Work and Pensions Research Report No. 416.

Blanchflower, D. and Bryson, A. (2008) Union Decline in Britain, CEP Discussion Paper No 846, London School of Economics. 
Blanden, J., Machin, S. and Van Reenen, J. (2006) Have Unions Turned the Corner? New Evidence on Recent Trends in Union Recognition in UK Firms, British Journal of Industrial Relations, 44(2), 169-190.

Blau, F. and Kahn, L. (2000), Gender Differences in Pay, Journal of Economic Perspectives, $14(4), 75-99$.

Booth, A. (2009), Gender and competition, Labour Economics, 16, 599 - 606.

Booth, A., and Nolen, P. (2012), Choosing to compete: How different are girls and boys? Journal of Economic Behaviour and Organization, 81, 542 - 555.

Brown, W. and Nash, D. (2008), What has been happening to collective bargaining under New Labour? Interpreting WERS 2004, Industrial Relations Journal, 39(2), 91-103.

Cobble, D. (2007), The Sex of Class: Women Transforming American Labor, Ithica: Cornell University.

Croson, R. and Gneezy, U. (2009), Gender differences in preferences, Journal of Economic Literature, 47 (2), $448-474$.

Department for Business, Innovation and Skills; Advisory, Conciliation and Arbitration Service, and National Institute of Economic and Social Research. (2015). Workplace Employee Relations Survey, 2011. 6th Edition. UK Data Service. SN: 7226.

Dickens, L. (1997), Gender, race and employment equality in Britain: inadequate strategies and the role of industrial relations actors, Industrial Relations Journal, 28 (4) 282289.

Disney, R., Gosling, A. and Machin, S. (1995) British unions in decline: an examination of the 1980s fall in trade union recognition, Industrial and Labor Relations Review, 48, 403419.

Donado, A. and Walde, K. (2012), How Trade Unions Increase Welfare, Economic Journal, Published Online on 09 March 2012, DOI: 10.1111/j.1468-0297.2012.02513.x 
Eckel, C. and Grossman, P. (2008), Men, women and risk aversion: experimental evidence, vol. 1, pp. 1061 - 1073, in Plott, C. and Smith V. (eds.), Handbook of Experimental Economics Results, Elsevier, Amsterdam.

Freeman, R. and Medoff, J. (1984), What do Unions Do? Basic Books.

Freeman, R. and Pelletier, J. (1990), The impact of industrial relations legislation on British union density, British Journal of Industrial Relations, 28 (2), 141-164.

Gneezy, U., Niederle, M. and Rustichini, A. (2003), Performance in competitive environments: gender differences, The Quarterly Journal of Economics, 118 (3), 1049 - 1074.

Green, A. and Kirton, G. (2006) Trade Unions and Equality and Diversity in Konrad, A., Prasad, P. and Pringle, J. (eds.) Handbook of Workplace Diversity, Sage Publications, London.

Haile, G. (2016) Union decline in Britain: does gender have anything to do with it? Scottish Journal of Political Economy, DOI: 10.1111/sjpe.12116.

Healy, G. and Kirton, G. (2000) Women, Power, and Trade Union Government, British Journal of Industrial Relations, 38 (3), 343-360.

Healy, G. and Kirton, G. (2013), The early mobilization of women union leaders - a comparative perspective, British Journal of Industrial Relations, 51 (4), 709 - 732.

Hotchkiss, J. and Pitts, M. (2007), The Role of Labor Market Intermittency in Explaining Gender Wage Differentials, The American Economic Review, 97 (2), pp. 417-421.

Howell, C. (1996), Women as the paradigmatic trade unionists? New work, new workers and new trade union strategies in Conservative Britain, Economic and Industrial Democracy, 17(4), 511-543.

HSE (2009), Historical picture: Workplace injury and ill health trends following the introduction of the Health and Safety at Work Act 1974, http://www.hse.gov.uk/STATISTICS/history/index.htm (accessed 24/11/16). 
Kersley, B., Alpin, C., Forth, J., Bryson, A., Bewley, H., Dix, G. and Oxenbridge, S. (2006). Inside the Workplace: Findings from the 2004 Workplace Employment Relations Survey, Routledge.

Kirton, G. (2006), 'Alternative or parallel careers for women: the case of trade union participation', Work, Employment and Society, 20(1): 47-66.

Kirton, G. \& Greene, A. (2002) Positive Action in Trade Unions: The Case of Women and Black Members, Industrial Relations Journal, 2, 157-172.

Kirton, G. (2015), Progress towards gender democracy in UK unions 1987 - 2012, British Journal of Industrial Relations, 53 (3), 484 - 507.

Machin, S. (2000) Union Decline in Britain, British Journal of Industrial Relations, 38 (4), 631-645.

Machin, S. (2003) Trade union decline, new workplaces and new workers (Chapter 2) in Gospel, H. and Wood, S. (eds.) Representing Workers: trade union recognition and membership in Britain, Routledge, London.

Malcomson, J. (1983) Trade Unions and Economic Efficiency, Economic Journal, 93, 51-65.

Metcalf, D. (2000), 'Fighting for equality', Centrepiece, The Magazine for Economic Performance.

Niederle, M. and Vesterlund, L. (2007), Do women shy away from competition? Do men compete too much? The Quarterly Journal of Economics, 122 (3), 1067 - 1101.

Office for National Statistics (2014), Participation rates in the UK labour market: 2014, Office for National Statistics.

Papke, L. and Wooldridge, J. (1996), Econometric Methods for Fractional Response Variables with an Application to 401 (K) Plan Participation Rates, Journal of Applied Econometrics, 11 (6), 619-632. 
Parker, J. (2002), Women's groups in British unions, British Journal of Industrial Relations, $40(1), 23-48$.

Parker, J. (2006), Trade union women's groups and their effects on union goals and strategies, Human Resource Management Journal, 16 (4), 411-431.

Phipps, S., Burton, P. and Lethbridge, L. (2001), In and out of the Labour Market: Long-Term Income Consequences of Child-Related Interruptions to Women's Paid Work, The Canadian Journal of Economics, 34 (2), 411-429.

Riach, P. and Rich, J. (2006) An Experimental Investigation of Sexual Discrimination in Hiring in the English Labor Market, The B.E. Journal of Economic Analysis and Policy, 6 (2), Article 1.

Stuart, M., Tomlinson, J. and Lucio, M. (2013), Women and the Modernization of British Trade Unions: Meanings, Dimensions and the Challenge of Change, Journal of Industrial Relations, 55 (1), 38-59.

Van Wanrooy, B., Bewley, H., Bryson, A., Forth, J., Freeth, S., Stokes, L. and Wood, S. (2013), Employment Relations in the Shadow of Recession: findings from the 2011 Workplace Employment Relations Study, Palgrave, Macmillan, London.

Vickerstaff, S; Phillipson, C and Wilkie, R (2012), Work Health and Wellbeing. Bristol: Policy Press.

Waddington, J., and Whitston, C. (1997), Why do people join unions in a period of membership decline? British Journal of Industrial Relations, 35 (4), 515 - 546.

Williams, R. (2017), Analysing Proportions: Fractional Response and Zero One Inflated Beta Models, University of Notre Dame, https://www3.nd.edu/ rwilliam/stats3/FractionalResponseModels.pdf (accessed 20/09/2017). 
Figure 1: Estimated Union Density and \% Female Patterns, WERS2004 and 2011
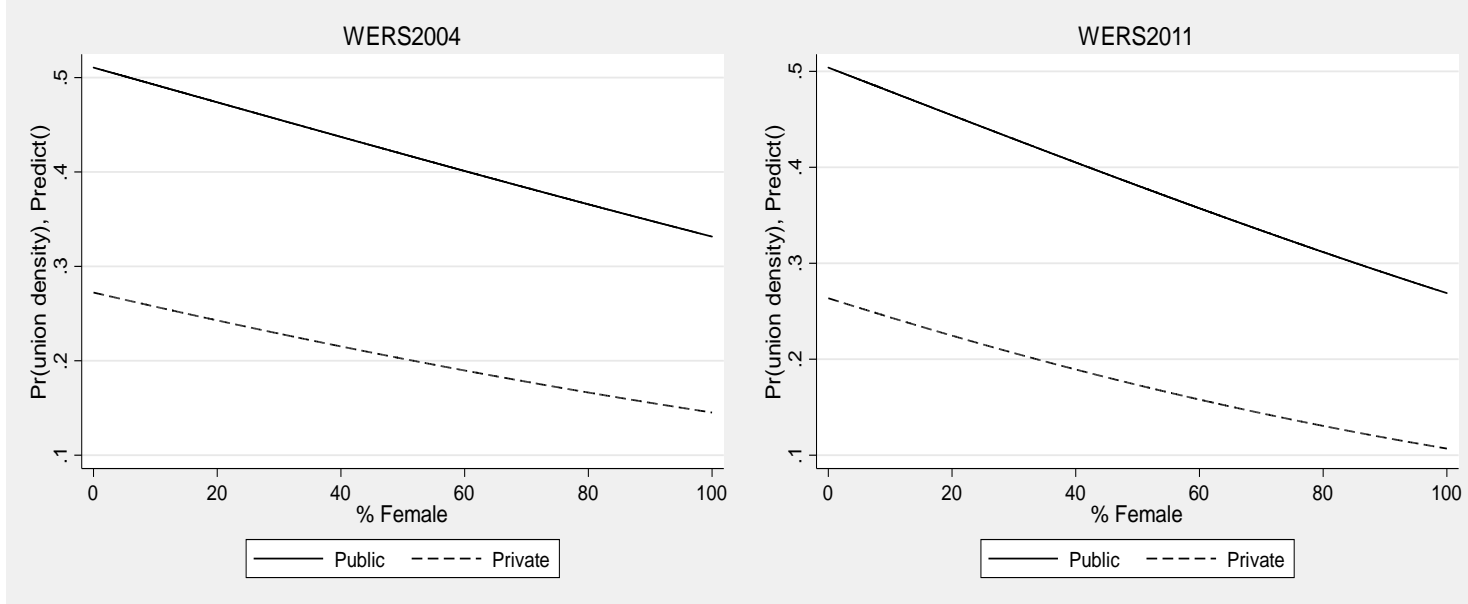
Table 1: Marginal Effects from Multilevel Mixed-Effects Logistic Model (Pooled 2004 \& 2011)

\begin{tabular}{|c|c|c|c|c|c|c|}
\hline & All & Private & Public & All & Private & Public \\
\hline \multirow[t]{2}{*}{ Male } & $0.0785 * * *$ & $0.0603 * * *$ & $0.0245 * * *$ & $0.0625 * * *$ & $0.0480 * * *$ & $0.0269 * * *$ \\
\hline & $(0.0106)$ & $(0.0163)$ & $(0.0081)$ & $(0.0104)$ & $(0.0166)$ & $(0.0082)$ \\
\hline $\begin{array}{l}\text { Employee } \\
\text { characteristics }\end{array}$ & yes & yes & yes & yes & yes & yes \\
\hline $\begin{array}{l}\text { Workplace } \\
\text { characteristics }\end{array}$ & no & no & no & yes & yes & yes \\
\hline \multirow[t]{2}{*}{2011} & -0.0207 & 0.0049 & 0.0001 & -0.0068 & 0.0177 & 0.0006 \\
\hline & $(0.0169)$ & $(0.0255)$ & $(0.0097)$ & $(0.0161)$ & $(0.0252)$ & $(0.0095)$ \\
\hline \multirow[t]{2}{*}{$\operatorname{Ln}\left(\sigma^{2}\right) \_$workplace } & $2.3864 * * *$ & $2.8489 * * *$ & $0.4793 * * *$ & $2.1826 * * *$ & $2.6291 * * *$ & $0.4432 * * *$ \\
\hline & $(0.1299)$ & $(0.1978)$ & $(0.0640)$ & $(0.1195)$ & $(0.1840)$ & $(0.0621)$ \\
\hline No. of employees & 22,536 & 11,619 & 10,917 & 22,536 & 11,619 & 10,917 \\
\hline No. of workplaces & 3214 & 2105 & 1109 & 3214 & 2105 & 1109 \\
\hline
\end{tabular}

Standard errors in parentheses $* * * \mathrm{p}<0.01, * * \mathrm{p}<0.05, * \mathrm{p}<0.1$ 
Table 2: Marginal Effects from Multilevel Mixed-Effects Logistic Model (Pooled 2004 \& 2011)

\begin{tabular}{|c|c|c|c|c|c|c|}
\hline & All & Private & Public & All & Private & Public \\
\hline \multirow[t]{2}{*}{ Male } & $-0.0518 * *$ & -0.0120 & $-0.0801 * * *$ & $-0.0495 * *$ & -0.0118 & $-0.0767 * * *$ \\
\hline & $(0.0254)$ & $(0.0362)$ & $(0.0216)$ & $(0.0247)$ & $(0.0365)$ & $(0.0216)$ \\
\hline \multirow[t]{2}{*}{$\%$ Female } & $-0.0029 * * *$ & -0.0009 & -0.0004 & $-0.0017 * * *$ & 0.0007 & -0.0004 \\
\hline & $(0.0004)$ & $(0.0006)$ & $(0.0003)$ & $(0.0004)$ & $(0.0007)$ & $(0.0003)$ \\
\hline \multirow[t]{2}{*}{ Male * \% Female } & $0.0017 * * *$ & $0.0014 * *$ & $0.0018^{* * *}$ & $0.0020 * * *$ & $0.0017 * * *$ & $0.0018 * * *$ \\
\hline & $(0.0004)$ & $(0.0006)$ & $(0.0003)$ & $(0.0004)$ & $(0.0007)$ & $(0.0003)$ \\
\hline $\begin{array}{l}\text { Employee } \\
\text { characteristics }\end{array}$ & yes & yes & yes & yes & yes & yes \\
\hline $\begin{array}{l}\text { Employer } \\
\text { characteristics }\end{array}$ & no & no & no & yes & yes & yes \\
\hline \multirow[t]{2}{*}{2011} & -0.0189 & 0.0045 & 0.0001 & -0.0071 & 0.0156 & 0.0008 \\
\hline & $(0.0169)$ & $(0.0256)$ & $(0.0096)$ & $(0.0160)$ & $(0.0252)$ & $(0.0094)$ \\
\hline \multirow[t]{2}{*}{$\operatorname{Ln}(\sigma)$ _workplace } & $2.4198 * * *$ & $2.8798 * * *$ & $0.4544 * * *$ & $2.1848 * * *$ & $2.6087 * * *$ & $0.4035 * * *$ \\
\hline & $(0.1319)$ & $(0.2016)$ & $(0.0622)$ & $(0.1205)$ & $(0.1848)$ & $(0.060)$ \\
\hline No. of employees & 22,536 & 11,619 & 10,917 & 22,536 & 11,619 & 10,917 \\
\hline No. of workplaces & 3214 & 2105 & 1109 & 3214 & 2105 & 1109 \\
\hline
\end{tabular}

Standard errors in parentheses

$* * * \mathrm{p}<0.01, * * \mathrm{p}<0.05, * \mathrm{p}<0.1$ 
Table 3: Union Density and \% Female, Marginal Effects form Generalised Linear Models (WERS2004 \& 2011, Pooled and Cross-sections of Workplaces)

\begin{tabular}{|c|c|c|c|}
\hline & All & Private & Public \\
\hline \multicolumn{4}{|l|}{ Pooled $2004 \& 2011$} \\
\hline \multirow[t]{2}{*}{$\%$ Female } & $-0.0016 * * *$ & $-0.0015 * * *$ & -0.0007 \\
\hline & $(0.000)$ & $(0.000)$ & $(0.001)$ \\
\hline Workplace characteristics & yes & yes & yes \\
\hline No. of workplaces & 4380 & 3231 & 1149 \\
\hline \multicolumn{4}{|l|}{ WERS2004 } \\
\hline \multirow[t]{2}{*}{$\%$ Female } & $-0.0015 * * *$ & $-0.0012 * * *$ & $-0.0014^{*}$ \\
\hline & $(0.000)$ & $(0.000)$ & $(0.001)$ \\
\hline Workplace characteristics & yes & yes & yes \\
\hline No. of workplaces & 2,050 & 1,552 & 498 \\
\hline \multicolumn{4}{|l|}{ WERS2011 } \\
\hline \multirow[t]{2}{*}{$\%$ Female } & $-0.0018 * * *$ & $-0.0017 * * *$ & -0.0001 \\
\hline & $(0.000)$ & $(0.000)$ & $(0.001)$ \\
\hline Workplace characteristics & yes & Yes & yes \\
\hline No. of workplaces & 2,330 & 1,679 & 651 \\
\hline
\end{tabular}

Standard errors in parentheses

$* * * \mathrm{p}<0.01, * * \mathrm{p}<0.05, * \mathrm{p}<0.1$ 
Table 4: Union Density and \% Female, Estimates from Linear Panel Data Models (Pooled OLS, RE \& FE; WERS2004 and 2011)

\begin{tabular}{|c|c|c|c|}
\hline & All & Private & Public \\
\hline \multicolumn{4}{|l|}{$O L S$} \\
\hline \multirow{2}{*}{$\%$ Female } & $-0.0023 * * *$ & $-0.0023 * * *$ & $-0.0018 * *$ \\
\hline & $(0.000)$ & $(0.000)$ & $(0.001)$ \\
\hline Workplace characteristics & yes & yes & yes \\
\hline \multirow{2}{*}{2011} & -0.0199 & -0.0133 & -0.0179 \\
\hline & $(0.013)$ & $(0.014)$ & $(0.025)$ \\
\hline \multirow[t]{2}{*}{ Constant } & $0.4482 * * *$ & $0.3270 * * *$ & $0.5723 * * *$ \\
\hline & $(0.054)$ & $(0.061)$ & $(0.124)$ \\
\hline R-squared & 0.475 & 0.388 & 0.250 \\
\hline No. of workplaces & 1,543 & 1,096 & 447 \\
\hline \multicolumn{4}{|l|}{ Random Effects Model } \\
\hline \multirow[t]{2}{*}{$\%$ Female } & $-0.0019 * * *$ & $-0.0019 * * *$ & $-0.0014 *$ \\
\hline & $(0.000)$ & $(0.000)$ & $(0.001)$ \\
\hline Workplace characteristics & yes & yes & yes \\
\hline \multirow{2}{*}{2011} & $-0.0190 * *$ & $-0.0174 * *$ & -0.0114 \\
\hline & $(0.009)$ & $(0.009)$ & $(0.020)$ \\
\hline \multirow[t]{2}{*}{ Constant } & $0.4683 * * *$ & $0.3649 * * *$ & $0.5385 * * *$ \\
\hline & $(0.055)$ & $(0.057)$ & $(0.141)$ \\
\hline R-squared (overall) & 0.47 & 0.38 & 0.24 \\
\hline Wald Chi2(.)/Prob. > chi2 & $795.4 / 0.000$ & $840 / 0.000$ & $88.42 / 0.000$ \\
\hline No. of workplaces & 1,543 & 1,096 & 447 \\
\hline \multirow[t]{2}{*}{ No. of unique workplaces } & 773 & 568 & 244 \\
\hline & & & \\
\hline \multirow[t]{2}{*}{$\%$ Female } & -0.0016 & $-0.0017 *$ & 0.0015 \\
\hline & $(0.001)$ & $(0.001)$ & $(0.002)$ \\
\hline Workplace characteristics (time varying) & yes & yes & yes \\
\hline \multirow[t]{2}{*}{2011} & $-0.0180 * *$ & $-0.0218 * *$ & -0.0054 \\
\hline & $(0.008)$ & $(0.009)$ & $(0.022)$ \\
\hline \multirow[t]{2}{*}{ Constant } & $0.3146 * * *$ & $0.1829 * *$ & $0.4310 *$ \\
\hline & $(0.089)$ & $(0.088)$ & $(0.260)$ \\
\hline R-squared (within) & 0.043 & 0.081 & 0.085 \\
\hline $\mathrm{F}(.,$.$) / Prob. >\mathrm{F}$ & $1.40 / 0.097$ & $1.93 / 0.006$ & $0.85 / 0.656$ \\
\hline No. of workplaces & 1,543 & 1,096 & 447 \\
\hline No. of unique workplaces & 773 & 568 & 244 \\
\hline
\end{tabular}

Standard errors in parentheses

$* * * \mathrm{p}<0.01, * * \mathrm{p}<0.05, * \mathrm{p}<0.1$ 